ISSN 1817-3721, E-ISSN 1818-8745

- Review paper

Plant Tissue Cult. \& Biotech. 29(2): 133-149, 2019 (June)

(CBangladesh Assoc. for Plant Tissue Culture \& Biotechnology

\title{
Recent Advances in Phalaenopsis Orchid Improvement using Omics Approaches
}

\author{
Khosro Balilashaki*, Hedayat Zakizadeh, Jamal-Ali Olfati, Maryam \\ Vahedi ${ }^{1}$, Anuj Kumar ${ }^{2}$ and Meera Indracanti ${ }^{3}$ \\ Department of Horticultural Sciences, Faculty of Agriculture, Guilan University, Rasht, Iran
}

Key words: Phalaenopsis, Orchid, Genomics, Omics approaches

\begin{abstract}
With recent advances in high-throughput sequencing (HTS) technologies to improve plants, there is a need to release orchid specific genomic resources and platforms that are crucial for managing omics elements in systematic manner. Authors provide details about the recent developments in biotechnological techniques, genomics, transcriptomics, proteomics, metabolomics and their applications for the industrial production, propagation, conservation and manipulation of Phalaenopsis orchid.
\end{abstract}

\section{Introduction}

Phalaenopsis belongs to most diverse, second largest and widespread family Orchidaceae, which comprises more than 25,000 species, prominently monopodial epiphytes (Averyanov and Averyanov 2006, Sheelavanthmath et al. 2005). Orchid flower is complex and typically zygomorphic with attractive odor components for pollinators like bees, moths, flies and birds (Cozzolino and Widmer 2005).

In recent years, there is a rise in market value of orchid flowers in international business (Tsai 2011). Orchids are the second most economically valued in USA (USDA 2006). To date, Phalaenopsis has been identified as the most popular potted orchids in the world (Minh et al. 2017). Several countries such as Thailand, Malaysia, Singapore, South Korea, and Sri Lanka cultivate orchids as a cash crop and Taiwan tops in the world production (Khoddamzadeh et al. 2011).

\footnotetext{
*Author for correspondence: <khosrobali@alumni.ut.ac.ir>. ${ }^{1}$ Department of Horticultural Science, Faculty of Agricultural Sciences and Engineering, College of Agriculture and Natural Resources, University of Tehran, Karaj, Iran. 2Advance Center for Computational \& Applied Biotechnology, Uttarakhand Council for Biotechnology (UCB), Dehradun-248007, Uttarakhand, India. ${ }^{3}$ Department of Agricultural Biotechnology, Institute of Biotechnology, University of Gondar, Gondar, Amhara, Ethiopia.
}

DOI: https://doi.org/10.3329/ptcb.v29i1.41986 
Unregulated flower collection and destruction of plant habitat are resulting in reduction of orchid's diversification (Vij and Pathak 2012). Microscopic seed size, lack of endosperm with less than $5 \%$ germination rates and requirement of species-specific mycorrhizal fungi during germination (Shefferson et al. 2005, Bonnardeaux et al. 2007) and production of heterozygous plants are major limitations of seed propagation. To overcome the limitations seed propagation, in vitro clonal propagation protocols of Phalaenopsis hybrids has been developed using various vegetative parts of the plants (Teixeira da Silva et al. 2014, Vendrame and Khoddamzadeh 2016, Yeung 2017). Remarkable amount of research in micropropagation of Phalaenopsis played an important role in ex situ conservation (Khoddamzadeh et al. 2011, Vendrame and Khoddamzadeh 2016). Besides symbiotic germination approaches on Phalaenopsis, non-symbiotic germination technologies are also being used for mass propagation of orchids (Griesbach 2002). However, browning of culture owing to exudation of phenolics during micropropagation, fungi and bacterial contamination of explants and somaclonal variation are some of the challenges for successful in vitro culture (Khoddamzadeh et al. 2010).

Phalaenopsis species is a diploid plant with 38 chromosomes $(2 \mathrm{n}=2 \mathrm{x})$ and the genome size of $P$. equestris is the smallest among other species of Orchidaceae (Leitch et al. 2009). Several studies on transcriptome sequencing have provided new insights into the structural and functional organization of the Phalaenopsis genome (Hsiao et al. 2006). It also aided in understanding and identification of putative genes involved in recent biosynthesis pathway. Manipulation of the biosynthesis pathway of fragrance can be used to produce high levels of aroma into monoterpene biosynthesis whereas this character will increase economic value of Phalaenopsis hybrid flowers. There are only a few species of Phalaenopsis which have a distinctive aroma (Yeh et al. 2014). Although recent efforts have been focused on genes identification focusing on scent, color, shape of flora (Hsu et al. 2015), there are still some missing genes in these pathways. Hsiao et al. (2006) elucidate the aroma biosynthetic pathway. A total of 31 volatile compounds were identified from Phalaenopsis 'Nobby's Pacific Sunset' orchids (Yeh et al. 2014).

Biologically active compounds such as phenolics and flavonoids have been identified in Phalaenopsis spp. (Minh et al. 2016). Root extract could play a role as antioxidant components. Manako et al. (2001) reported two phenanthropyran derivatives from $P$. equestri. Presence of pyrrolizidine alkaloid from root tips and young flower buds of Phalaenopsis orchids was reported by Anke et al. (2008).

This review provides details about the recent developments in biotechnological techniques, genomics and their applications for the industrial production, propagation, conservation and manipulation of Phalaenopsis orchid.

Plant tissue culture approaches: The improvement of biotechnological approaches aid in improving floricultural species for commercial production of orchid (Hossain et al. 2013). 
In the recent years, several reports on micropropagation of Phalaenopsis orchids show that selection of suitable explants are the critical factors for the success of plant tissue culture (Vasil et al. 2008, Vendrame and Khoddamzadeh et al. 2016). Composition of media also significantly affect the induction, number and plant regeneration efficiency in Phalaenopsis. (Kosiret et al. (2004) has been reported six medium compositions for direct shoot regeneration of Phalaenopsis. Plant regeneration in many genera has been achieved through flower stalks bud, stem nodes (Balilashaki et al. 2014), leaf tissues (Mayer et al. 2010, Niknejad et al. 2011, Vendrame and Khoddamzadeh 2016), shoot tips (Pant and Thapa et al. 2012). Sinha et al. (2010) studied the vegetative propagation of Phalaenopsis using young leaf segments on gelrite-gelled half strength MS supplemented with $2 \%$ sucrose, $2.0 \mathrm{mg} / \mathrm{BA}, 0.5 \mathrm{mg} / \mathrm{NAA}, 10 \%$ coconut water $(\mathrm{CW}), 2 \mathrm{~g} /$ peptone and $1 \mathrm{~g} /$ activated charcoal, the protocorm like bodies (PLBs) were induced within 12 weeks of culture. PLB formation is considered either direct or indirect embryogenesis (Martin and Madassery et al. 2006, Hong et al. 2008). The clonal propagation on a large scale of Phalaenopsis via the culture of protocorms has been reported by Paek et al. (2011). They reported that genotype, seed maturity and media composition influence seed germination rate and protocorm formation. The in vitro regeneration of Phalaenopsis orchid also dependent on activated charcoal (absorbs ethylene and phenolic inhibitors) supplement in culture medium. Cytokinins in combination with auxins also have shown to induce the PLB formation from leaf sections (Niknejad et al. 2011). A successful method for mass propagation of PLBs of Phalaenopsis elucidates using bioreactor system where leaves emerging from nodes (Young et al. 2000). Kuo et al. (2005) reported factors affecting direct somatic embryogenesis in the orchid Phalaenopsis 'Little Steve'. Direct somatic embryogenesis was reported from leaf explants of Phalaenopsis amabilis (Chen and Chang et al. 2006). Feng and Chen (2014) developed an efficient protocol for regeneration of Phalaenopsis aphrodite subsp. Formosana via inducing direct somatic embryogenesis. The important economic targets for in vitro propagation of epiphytic orchids includes the creation of variation in leaf types, flower color, fragrance and plant shape. Raynalta et al. (2018) studied the clonal fidelity of micropropagated Phalaenopsis plantlets by using of SNAP markers, they showed that TDZ and polyvinylpyrrolidone (PVP) induced PLB from leaf explants. $11.8 \%$ possible variants out of 34 evaluated plantlets were seen based on the assessment SNAP markers. Reports showed in vitro technologies can improve the $e x$ situ conservation of orchid genetic resources (Aktar et al. 2008, An et al. 2011, Hossain et al. 2013).

Asymbiotic seed germination and the use of microbes has been reported in Phalaenopsis Blume orchids (Lesar et al. 2012). The influence of pollination season and maturity of capsule have been investigated under asymbiotic seed germination in three Phalaenopsis orchid hybrids, namely, 'Athens', 'Moscow' and 'Lusaka' flowers 
(Balilashaki et al. 2014). Winter season was the suitable seasons of pollination and the highest germination percentages observed in 5-month-old winter-pollinated capsules.

Genomics: Genomics study is difficult for Phalaenopsis orchid because of its larger genome size and long life cycles. The chromosome sizes of Phalaenopsis species ranging from 1.5 to $3.5 \mu \mathrm{m}$ are grouped into low, medium and high nuclear DNA content (Chen et al. 2010a). Lin et al. (2001) used flow-cytometry and estimated DNA contents of the nuclei in 18 Phalaenopsis Blume and Doritis pulcherrima Lindl. species. They observed a 6.07-fold variation in genome size within 18 Phalaenopsis species, ranging from $2.74 \mathrm{pg} /$ diploid nuclear DNA content (2C) for $P$. sanderiana to $16.61 \mathrm{pg} / 2 \mathrm{C}$ for $P$. parishii which suggested that the $2 \mathrm{C}$-values of the Phalaenopsis sp. correlate with their chromosome sizes and also observed highest degree of endoreduplication in P. equestris leaves. Through chromosomal doubling new commercial hybrids were produced in Phalaenopsis (Chen et al. 2010b) and these hybrids can be used for comparative analyses of DNA content on evolution of Phalaenopsis or help to the orchid breeders and molecular geneticists for the selection of parental varieties for hybridization. Kao et al. (2001) analyzed karyotypes of nine representative Phalaenopsis species and D. pulcherrima and reported genome size and the amount of constitutive heterochromatin $(\mathrm{CH})$ among the species. Molecular markers such as RFLP, RAPD and DAF used in diversity studies of Phalaenopsis. Goh et al. (2005) used RAPD markers for genetic distance and relationship investigation of 149 accessions in Phalaenopsis, they were useful for separation of the genus into seven clusters. RAPD analysis of 20 species of Phalaenopsis, was useful for producing genetic maps and markerassisted selection in crop plants (Niknejad et al. 2009). Sequence-based microsatellite markers used for the study of molecular characterization and relationships (Fattmah and Sukma 2011) in orchids. Twenty-eight polymorphic microsatellite markers were screened for delimiting species within genus Phalaenopsis by Ko et al. (2017). cpDNA markers was used to compare P. equestris and P. aphrodite, they showed similar AT content, genome size, gene order and codon usage (Chang et al. 2017).

Genomic in situ hybridization (GISH) and RFLP analysis were conducted to identify the intergeneric hybridization status of putative hybrids. Both GISH and RFLP analyses were effective for $F_{1}$ hybrids detection (Liu et al. 2016a). The modified drop method has been improved by Kuo et al. (2016), it could be used for fluorescence in situ hybridization (FISH) mapping of DNA fragments in cytogenetic studies in Phalaenopsis orchids. FISH technique was used for chalcone synthase (CHS) localization on Phalaenopsis orchid chromosomes (Kuo et al. 2018) and also was used for detection of the accuracy of genome assembly of Phalaenopsis aphrodite (Chao et al. 2018).

The genome sequence of Phalaenopsis equestris (Cai et al. 2015) suggest that, gene duplication might have contributed to the CAM photosynthesis process in P. equestris and found MADS-box CD-class, B-class AP3 and AGL6-class genes, play role in morphology of orchid flowers. A draft genome for Phalaenopsis pulcherrima 'B8802' and 
Phalaenopsis 'KHM190' cultivars have been generated by Huang et al. (2016). The differences between two orchids allowed the identification of 691,532 single-nucleotide polymorphisms. They also discovered the gibberellins synthesis pathway that regulates the expression of flowering time genes during the reproductive phase in orchids.

Transcriptomics: Transcriptome approach is used to study of the total mRNA molecules, gene fusions, and allele specific expression patterns with a clear, complete view from the molecular mechanisms of floral transcription in orchids. There are several reports on gene expression of orchid flower. Chalcone synthase (CHS), is the key gene in flavonoid biosynthesis pathway was isolated from Phalaenopsis hybrid flowers (Han et al. 2006), highly expressed Pchs1 in petals and lips concomitant with the accumulation pattern of the anthocyanin in its flowers. Floral pigmentation patterning was studied in Phalaenopsis spp., and three R2R3-MYB transcription factors PeMYB2, PeMYB11, and $P e M Y B 12$ were detected concomitant with red color formation in different varieties of tissues such as sepals/petals and lip. PeMYB2, PeMYB11 and PeMYB12 were responsive to the anthocyanin production in the sepals/petals (Hsu et al. 2015).

Real-time RT-PCR analysis on selected ESTs (Expres sed Sequence Tags) showed that auxin-regulated protein kinase, cyclophilin, and TCP-like genes are upregulated in mutant flower buds (Chen et al. 2005). A total of 5593 ESTs obtained from the flower buds of Phalaenopsis equestris (diploid species of Phalaenopsis) whereas a unigene set of 3688 sequences were identified via cluster analysis (Tsai et al. 2006).

Hsiao et al. (2006) successfully compared the transcripts in Phalaenopsis bellina and Phalaenopsis equestris flowers. Enzymes in the monoterpenoids biosynthetic pathway were recognized through data mining of the $P$. bellina floral EST database (dbEST). Systematic computational approaches were used to characterize the microRNA (miRNA) in Phalaenopsis aphrodite. A sum of 23 novel miRNAs expressed in the flower, their targets was predicted by miRBase in P. aphrodite (Chao et al. 2014). Huang et al. (2016) reported draft sequence and assembly of the genome of Phalaenopsis 'KHM190' cultivar generated 89.5 Gb RNA-seq and 113 million sRNA-seq reads for identifying 188 miRNA families.

There are several reports available on the orchid MADS-Box genes encoding transcriptional factors which are employed for the important roles on orchid floral development and evolutionary studies. Based on the exon/intron and domain structures, this ABCDE gene family is divided into two lineages, type I and type II in orchids (Smaczniak et al. 2012). Previous analysis of the patterns of expression in the floral organs of Phalaenopsis equestris orchid MADS-box genes identified and characterized four B-class Phalaenopsis DEF-like MADS-box genes, including PeMADS2, PeMADS3, PeMADS4 and PeMADS5 that they may play distinctive morphogenetic roles in the flowers (Tsai et al. 2006). Miranda and Palomino (2014) tested eight MADS-box candidate SEP-, FUL-, AG-, and STK-like genes in wild-type and peloric Phalaenopsis flowers. Their result represented that SEPALLATA-like genes cleaved in two major clades, SEP1, 2, 4- 
like genes by four sub-clade OsMADS1, OsMADS5, und RMADS217-like genes (OsMADS34) and SEP3-like gene (divided in three major groups) which expressed in all flower organs.

Advances in sequencing technologies and a functional genomic study in orchids reported by Su et al. (2011), where they employed two strategies, high-throughput sequencing platform technologies, Roche 454 and Illumina Solexato maximize assembly output. C- and a D-class gene, PeMADS1 and PeMADS7 in Phalaenopsis equestris are involved in evolution, orchid gynostemium and ovule developmental processes (Chen et al. 2012). The first transcriptome analysis based on deep sequencing was reported by Tsai et al. (2015) for developing EST-SSR loci in P. aphrodite subsp. formosana. They obtained a total of 1,439 EST-SSR loci, including di-, tri-, tetra-, penta- and hexanucleotide motifs from Phalaenopsis species whereas di- and tri-nucleotide detected as two most frequent motifs in this orchid species. Transcriptome and expression profile analysis during Phalaenopsis explant browning in vitro culture assayed by $\mathrm{Xu}$ et al. (2015), functional annotation led to the discovery of different expressed gene (DEGs) mainly involved in phenylpropanoid pathway and flavonoid biosynthesis. Previous studies reported significant changes in those two pathway (Jones and Saxena 2013). Transcriptome sequencing using Illumina platform from floral organ tissues (sepal, petal, labellum and gynostemium) of the Phalaenopsis wild-type and peloric mutant has revealed the critical regulators of the MADS-box TFs in Phalaenopsis labellum formation, and also identified five MADS genes, PhAGL6a (CUFF.17763), PhAGL6b (CUFF.17763.1), PhMADS1 (CUFF.36625.1), PhMADS4 (CUFF.25909) and PhMADS5 (CUFF.39479.1) genes with differential expression in floral-organ development in Phalaenopsis. An increased PhMADS4, PhAGL6a and PhAGL6b transcript levels observed in lip-like petals and liplike sepals of peloric mutant flowers whereas PhMADS1 transcript was expressed strongly in the gynostemium of both wild types and peloric mutants and the PhMADS5 transcript level showed a positive regulator of petal and sepal development (Huang et al. 2015) and identified the four isoforms of PhAGL6b on the C-terminus region with the MADS-box genes as potential regulatory components of labellum organ development which involved alternative splicing in the big lip mutant (Huang et al. 2016). They showed the expression of flowering time genes control by the gibberellin synthesis pathway. Genome and transcriptome information help the genetic improvement and breeding of the Phalaenopsis orchids. De novo transcript sequence reconstruction from RNA-seq using the Trinity platform for 11 diverse P. equestris tissue performed by Niu et al. (2016), and obtained transcriptomes from root, stem, seed and floral organs, and found 24, 21, 22 and 7 disease resistance (R) genes in the flower bud, root, stem and in the 7-day-seeds, respectively and did not observe the YABBY gene family (use in determining leaf polarity) in roots and seeds. Eight transcripts have been identified during the comparative transcriptome analysis between scented and scentless orchids, 
among them PbbHLH4 regulates floral monoterpene biosynthesis in Phalaenopsis orchid (Chuang et al. 2018). Phalaenopsis flowering locus VE (PaFVE) gene has been characterized by Koh et al. (2018) via spatial and temporal expression studies. It regulates floral organ maturation and flowering time.

Proteomics: Systematic study of the orchid genome has generated a lot of information in the past. Genome annotation has discovered a number of new orchid genes not previously known in production and evolutionary biology (Cai et al. 2015). Several research efforts have been undertaken targeting on enhancement of orchid properties using proteomics-based methods including two-dimensional electrophoresis (2-DE) and mass spectrometry. Proteomics-based applications have been applied in orchid for mass production, mycorrhizal fungi interaction, drought stress and cell cycle regulation (Hsiao et al. 2011, Hossain et al. 2013). Liao et al. 2004, made a proteomic effort for CymMV capsid protein gene known for its role to silence the $P$. amabilis and enhances its resistance to CymMV. It has been reported that expression of exogenous lipid transfers protein-encoding gene responsible for improving the plants frost resistance (Qin et al. 2011). Lai et al. (2013) identified 27 novel differentially expressed proteins by using twodimensional electrophoresis and further examined them by mass spectrometry. Functional annotation of these proteins revealed that they play a critical role in wide range of biological processes including disease resistance, stress response, transcriptional regulation, energy metabolism, and protein modification. Identified proteins may provide new insights towards understanding of the interactive responses in protein expression of $P$. amabilis during infection with CymMV and/or ORSV. Chen et al. (2018) reported a combined proteomic approach with ultrastructural observation and physiological-biochemical analysis during pollination-induced petal senescence in Phalaenopsis and yielded 42 differentially regulated proteins. Out of 42 proteins, 17 were found upregulated, while 25 were down regulated. Identification and functional characterization of differentially regulated proteins can be utilized as putative markers of senescence in Phalaenopsis.

The two-dimensional electrophoresis and LCMSMS have been used to show the differential expressions of $P s b P$ and $P s b O$ between the green and yellow leaf sectors of a variegated mutant of Phalaenopsis aphrodite subsp. Formosana (Tsi et al. 2017). Proteomic changes via matrix-assisted laser desorption/onization time of flight mass spectrometry (MALDI-TOF/TOF-MS) has been examined by Chen et al. (2018) to reveal the mechanism regulation of petal senescence in Phalaenopsis.

In spite of various bioinformatics based algorithms and tools available for functional annotation and protein structure modeling, extensive analysis was limited to a few selected protein families. For instance, UniProt hosts mere 1,011 protein entries for Phalaenopsis, of which only 74 reviewed; leaving a huge scope for both bioinformatics and in vitro studies. Currently, there is a demand for solved crystal structure or modeled 3D 
structures that can accelerate the Computer-Added Drug Design (CADD) to simulate drug-receptor interactions. Furthermore, 12 crystal structures for orchids are available in protein data bank (PDB) (http://www.rcsb.org/pdb/results/results.do? tabtoshow = Current and qrid = 1DCCD321) (Fig. 1), which could bridge that demand in finding insights into the above-mentioned mechanisms.

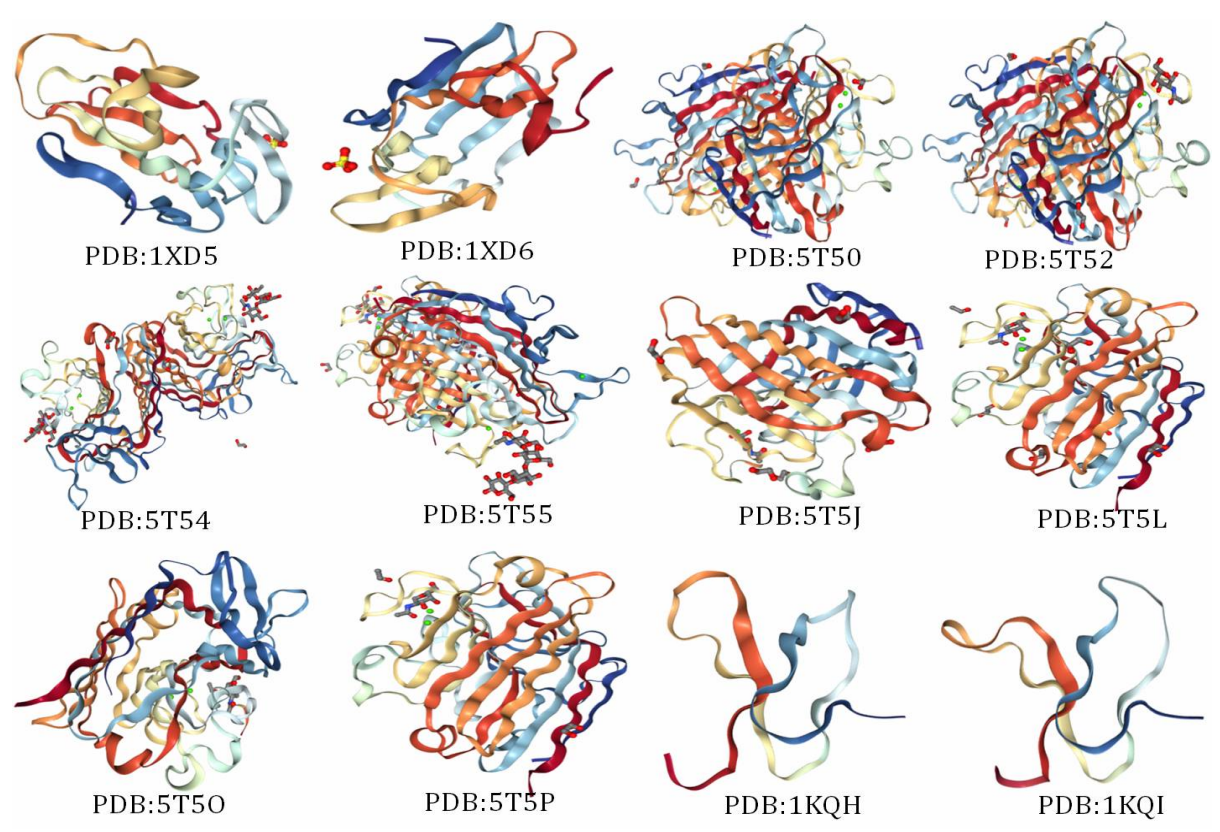

Fig. 1. 3D view of orchid protein structures available in protein data bank (PDB).

Metabolomics: 3\% of these total orchid plant-derived compounds are known (Gutierrez 2010, Qasem and Foy 2001) and there are a very few reports available on phytochemical and biochemical aspects of orchids as a potential source of medicinal property. Recent advances in elucidating the biological properties of orchid species and its potential role in health-care suggest they can be used for treatment of various diseases such as anti-rheumatic, anti-carcinogenic, antivirus, antimicrobials, anticonvulsive, neuroprotective, and hypoglycemic activities (Gutierrez 2010, Yonzone et al. 2012; Marasini and Joshi 2013, Avasthi et al. 2013). Various studies on chemical components of orchids and suggest they possess phytoconstituents like phenols, alkaloids, glycosides, triterpenoids, flavonoids and stilbenoids (Gutierrez 2010, Kalaiarasan et al. 2011, Teoh 2016). According to Manako et al. (2001) study, spectroscopic (NMR, MS and so on) analysis identified 3-methoxy-2,7-dihydroxy-5H-phenanthro [4,5-bcd] pyran and 2,3,7trihydroxy-5H-phenanthro [4,5-bcd] pyran from Phalaenopsis equestris. The accumulation of different phenolic compounds examined by Andreotti et al. (2006) reported that 
amount of the phenols being synthesized in different parts of plant are affected by environmental conditions such as stress, UV- light and and so on. Ling and Subramaniam (2007) examined anthocyanins, anthocyanidins, chlorophylls, phenolics, proteins and sugar contents of 12 different samples of Phalaenopsis violacea and the reported cyaniding at a concentration of $11.53 \pm \mu \mathrm{g} / \mathrm{ml}$, delphinidin $(12.73 \pm 0.08 \mu \mathrm{g} / \mathrm{ml})$, malvidin $(7.65 \pm 0.05 \mu \mathrm{g} / \mathrm{ml})$, pelargonidin $(8.98 \pm 0.06 \mu \mathrm{g} / \mathrm{ml})$, peonidin $(21.24 \pm 0.13$ $\mu \mathrm{g} / \mathrm{ml})$ and petunidin $(117.12 \pm 0.69 \mu \mathrm{g} / \mathrm{ml})$. The protein and total phenol concentration obtained for Phalaenopsis violacea were $1.78 \pm 0$ and $55.00 \pm 4.15 \mu \mathrm{g}$, respectively. Frölich et al. (2006) suggested that pathways of typical compounds for plant secondary metabolism, orchidaceae alkaloids like T-phalaenopsine (necine base trachelanthamidine) more than $90 \%$ of total alkaloid and its stereoisomer Isphalaenopsine (necine base isoretronecanol) as two 1,2-saturated pyrrolizidine monoesters identified by GC-MS. Analysis of phalaenopsine biosynthesis with ${ }^{14} \mathrm{C}$ labeled putrecine indicated, the aerial roots of rosette plants were the sites of phalaenopsine biosynthesis. The tissue distribution of pyrrolizidine alkaloids in Phalaenopsis suggests in young and developing tissues (e.g., root tips and young leaves), peripheral tissues (e.g., of flower stalks) and reproductive organs (flower buds and flowers), has highest accumulation (Anke et al. 2008). Phalaenopsis orchids produce pyrrolizidine alkaloids of the phalaenopsine type as a defense factor that the first enzyme of pyrrolizidine alkaloid biosynthesis is homospermidine synthase (HSS) (Nurhayati et al. 2009). Anke et al. (2008) suggested no linkage was observed between plant development and HSS expression pattern (in the tips of aerial roots as the first site) and both of them independently happen during angiosperm evolution as expressed in a variety of tissues (Ober and Kaltenegger 2009).

Minh et al. (2016) investigated the leaves and roots extracts of six different hybrids of Phalaenopsis spp. For phenolic compounds and antiradical properties. They reported that the roots containing ferulic acid, $p$-coumaric acid, and sinapic acid and has extensive amount of natural antioxidants compared to leaves. Extracts from Dactylorhiza hatagirea (Orchidaceae) plant have been reported for its antibacterial activity (Dutta and Karn 2007). The medicinal potential of Dactylorhiza hatagirea was studied by Pant and Rinchen (2012) in traditional and modern medicine system. Kuo et al. (2010) detected the compositions of flavones and anthocyanin at 375 and $530 \mathrm{~nm}$ via high-performance liquid chromatography/ultraviolet detector (HPLCNV) in various Phalaenopsis hybrids with red flower color, eventually using the scavenging of the $\alpha, \alpha$-diphenyl- $\beta$-picrylhydrazyl $(\mathrm{DPPH})$ free radical assayed the antioxidant properties and also reported the antityrosinase activities of the pigment constituents. Compounds of (3',7-di-Osinapylglucosyl)-3-glucosyl cyaniding, saponarin and apigenin 6-C-ribosido-7-O- glucoside were observed with the IC 50 values of $27.3,307.1$ and $41.6 \mu \mathrm{M}$, respectively, and strong anti-tyrosinase activities was apperceived only by apigenin 6 - $\mathrm{C}$-ribosido-7-O-glucoside. 
Modification of the metabolic rate and the growth Phalaenopsis by genetic engineering has been studied by Chen et al. (2010), and selected Phalaenopsis transformed with the Vitreoscilla hemoglobin gene via injection of DNA solution into immature capsules and analyzed by Western blotting, eventually indicated line B47 has increased the growth in the vegetative and reproductive stage. The antimicrobial activity of Dendrobium nobile and Phalaenopsis flower extracts compared to five different antibiotics pyogenic skin infections isolates which the promising result were observed in case of flower extracts of Dendrobium nobile and Phalaenopsis that have been rich in key metabolites (Ashraf et al. 2013). Based on data obtained from metabolites of Phalaenopsis species can be used in the development of novel pharmaceutical sciences. The sucrose concentration in the stem significantly was increased at dawn and dusk of Phalaenopsis aphroide after warmnight treatment, so sucrose in the stem might be playing an important role in to sustain the viability of the dormant spike bud. All leaves at dawn of Phalaenopsis aphroide contained the highest citrate concentration under the warm-night treatment. Citrate accumulation helps to protect the leaves from warm-night stress (Liu et al. 2013). The three light treatments; (1) $40 \%$ blue $60 \%$ red, (2) $100 \%$ red, and (3) $100 \%$ white (control) were employed (Ouzounis et al. 2014) in greenhouse systems of Phalaenopsis production, where they observed that leaf area and total fresh weight were highest in the 40\% B/60\% $\mathrm{R}$ and $100 \%$ red for Phalaenopsis 'Vivien' and Phalaenopsis 'Purple star', respectively. They also studied quantitation of secondary metabolites by HPLC and their results indicated the additional blue light increased amount of flavonoids and carotenoids in Phalaenopsis. LC-MS technique based metabolomics has been performed on the effects of light qualities on Phalaenopsis, obtained results were showed the different light environments affected on the compounds of Phalaenopsis, so the environment conditions plays an important role in chemical instability of Phalaenopsis orchid, and also observed the significant differences between the molecular weights that involved biosynthesis of alkaloids derived from shikimate pathway. This study would be helpful to produce commercial Phalaenopsis orchid (Liu et al. 2016 b) exploring the existing possibilities as highlighted above.

Bioinformatics data bases for orchid: Recent advances in high-throughput sequencing (HTS) technologies, coincident with dramatic declines in cost, have enabled the scientific community to screen the whole genome and generate hypothesis leading to improving plants. Further, recently released orchid specific genomic resources and platforms are crucial for managing omics elements in systematic manners and extraction of desired genomic information. Details of important orchid databases have been shown in Table 1.

In this review, authors have summarized recent developments in genetics, genomics and their applications for the industrial production of Phalaenopsis orchid. The new hybrids produced through somaclonal variants are used for the production of important metabolites. These could be better explored through the genome databases and important networks can be constructed which will further improve this value of the orchids. 


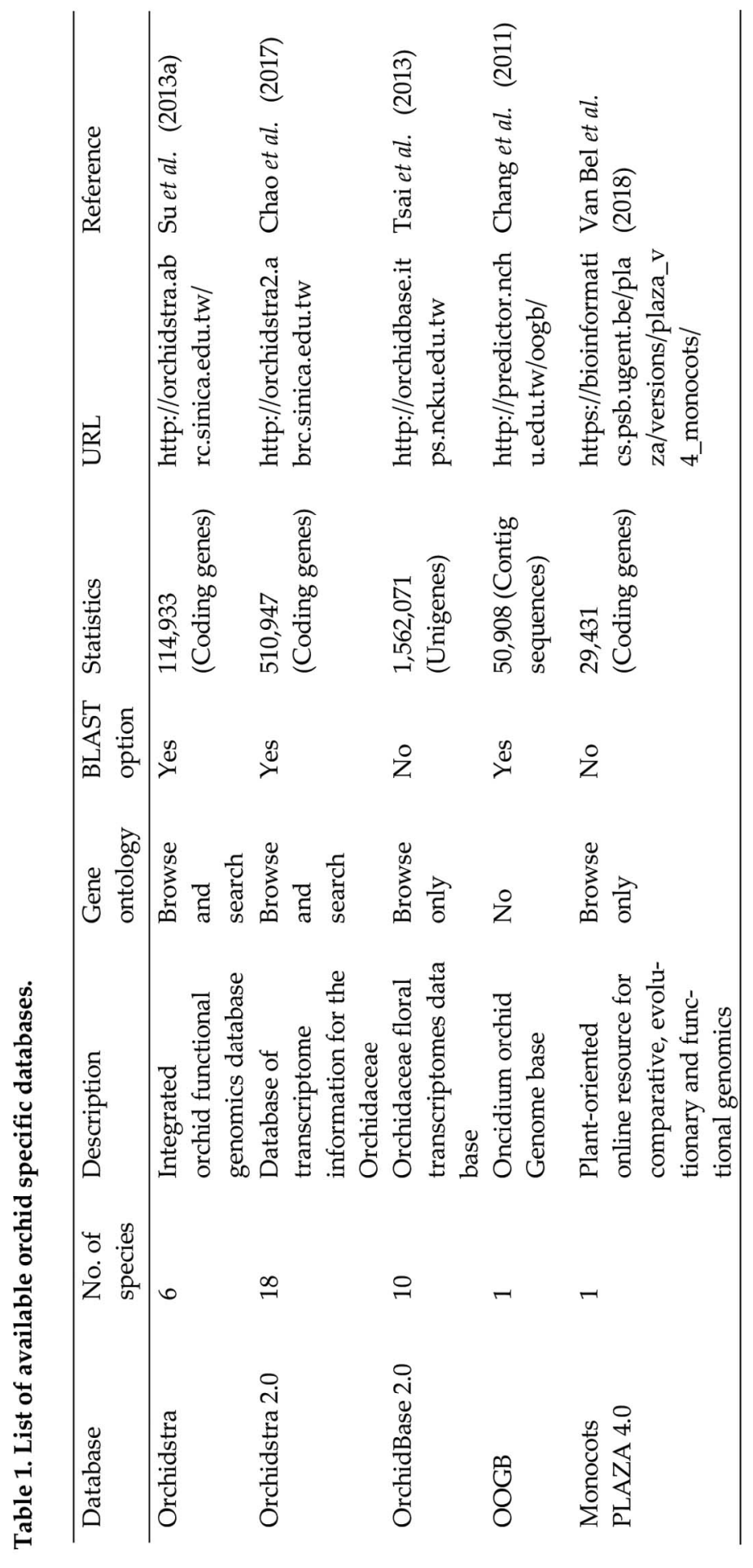




\section{References}

Aktar S, Nasiruddin KM and Hossain K (2008) Effects of different media and organic additives interaction on in vitro regeneration of Dendrobium orchid. J. Agric. Rural Dev. 6(1): 69-74.

An FM, Hsiao SR and Chan MT (2011) Sequencing-based approaches reveal low ambient temperature-responsive and tissue-specific microRNAs in Phalaenopsis orchid. PLoS One 6(5): e18937.

Andreotti C, Costa G and Treutte D (2006) Composition of phenolic compounds in pear leaves as affected by genetics, ontogenesis and the environment. Sci Hort. 109(2): 130-137.

Anke S, Gondé D, Kaltenegger E, Hänsch R, Theuring C and Ober D (2008) Pyrrolizidine alkaloid biosynthesis in Phalaenopsis orchids: Developmental expression of alkaloid-specific homospermidine synthase in root tips and young flower buds. Plant Phyiol. 148(2): 751-760.

Ashraf F, Bashir A, Mehmood S and Saeed B (2013) New horizon in therapeutics: Antimicrobial action of Dendrobium nobile and Phalaenopsis against pyogenic skin infection isolates. Indian J Health Wellbeing 4(7): 1452.

Avasthi SA, Ghosal SA and Purkayastha SH (2013) Study of antimicrobial activity of Orchislatifolia. Int J. Pharm. Bio. Sci. 4(4): 638-646.

Averyanov LV and Averyanova AL (2006) New orchids from Vietnam. Komarovia 4: 1-39.

Balilashaki K, Gantait S, Naderi R and Vahedi M (2012) Capsule formation and asymbiotic seed germination in some hybrids of Phalaenopsis, influenced by pollination season and capsule maturity. PhysiolMolecul Bio. Plants 21(3): 341-347.

Balilashaki K, Naderi R, Kalantari S and Soorni A (2014) Micropropagation of Phalaenopsis amabilis cv. Cool breeze with using of flower stalk nodes and leaves of sterile obtained from node cultures. Int. J. Farm Allied Sci. 3(7): 823-829.

Bonnardeaux Y, Brundrett M, Batty A, Dixon K, Koch J and Sivasithamparam K (2007) Diversity of mycorrhizal fungi of terrestrial orchids: Compatibility webs, brief encounters, lasting relationships and alien invasions. Mycol. Res. 111(1): 51-61.

Cai J, Liu X, Vanneste K, Proost S, Tsai WC, Liu KW, Chen, LJ, He Y, Xu Q, Bian C and Zheng Z (2015) The genome sequence of the orchid Phalaenopsis equestris. Nat. Genet. 47(1): 65-72.

Chang CC, Wu WL, Liu YC, Jheng CF, Chen TC, Lin BY, Lin JY, Chen TC and Lee YF (2017) Comparative chloroplast DNA Analysis of Phalaenopsis Orchids and Evaluation of cpDNA Markers for Distinguishing Moth Orchids. In: Orchid Biotechnology III (pp. 61-90).

Chao YT, Chen WC, Chen CY, Ho HY, Yeh CH, Kuo YT, Su CL, Yen SH, Hsueh HY, Yeh JH and Hsu HL (2018) Chromosome-level assembly, genetic and physical mapping of Phalaenopsis aphrodite genome provides new insights into species adaptation and resources for orchid breeding. Plant Biotech. J. 16(12): 2027-2041.

Chao YT, Su CL, Jean WH, Chen WC, Chang YCA and Shih MC (2014). Identification and characterization of the microRNA transcriptome of a moth orchid Phalaenopsis aphrodite. Plant Molecul. Bio. 84(4-5): 529-548.

Chen YH, Tsai YJ, Huang JZ and Chen FC (2005) Transcription analysis of peloric mutants of Phalaenopsis orchids derived from tissue culture. Cell Research 15(8): 639-657.

Chen JT and Chang WC (2006) Direct somatic embryogenesis and plant regeneration from leaf explants of Phalaenopsis amabilis. Biol. Plant 50(2): 169-173. 
Chen WH, Tang CY and Kao YL (2010a) Polyploidy and Variety Improvement of Phalaenopsis Orchids. In: International Orchid Symposium 878: 133-138.

Chen YC, Yang YC, Chen YH, Chao YP, Chang LZ and Chen YW (2010b) Modification of Phalaenopsis metabolism by genetic engineering. In: International Orchid Symposium. 878: 473-480.

Chen YY, Lee P F, Hsiao YY, Wu WL, Pan ZJ, Lee YI, Liu KW, Chen LJ, Liu ZJ and Tsai WC (2012) C-and D-class MADS-box genes from Phalaenopsis equestris (Orchidaceae) display functions in gynostemium and ovule development. Plant Cell Physiol. 53(6): 1053-1067.

Chen C, Zeng Land andYe Q (2018) Proteomic and Biochemical Changes during Senescence of Phalaenopsis 'Red Dragon' Petals. Int. J. Mol. Sci. 19(5).

Chuang YC, Hung Y C, Tsai WC, Chen WH and Chen HH (2018) PbbHLH4 regulates floral monoterpene biosynthesis in Phalaenopsis orchids. J. Exp. Bot. 69(18): 4363-4377.

Cozzolino Sand Widmer A (2005) Orchid diversity: an evolutionary consequence of deception? Trends Ecol. Evol. 20(9): 487-494.

Dutta IC and Karn AK (2007) Antibacterial Activities of some traditional used Medicinal plants of Daman, Nepal. Pokhara, Nepal: TU, IOF, and Com Form.

Fattmah and Sukma D (2011) Development of sequence-based microsatellite marker for Phalaenopsis orchid. HAYATI J Biosci. 18(2): 71-76.

Feng JH and Chen JT (2014) A novel in vitro protocol for inducing direct somatic embryogenesis in Phalaenopsis aphrodite without taking explants. Scientific World Journal 2014.

Frölich C, Hartmann T and Ober D (2006) Tissue distribution and biosynthesis of 1, 2-saturated pyrrolizidine alkaloids in Phalaenopsis hybrids (Orchidaceae). Phytochemist 67(14): 1493-1502.

Fu SF, Tsai TM, Chen YR, Liu CP, Haiso, LJ, Syue, LH, Yeh, HH and Huang HJ (2012) Characterization of the early response of the orchid, Phalaenopsis amabilis, to Erwinia chrysanthemi infection using expression profiling. Physiol. Plant 145(3): 406-425.

Goh MWK, Kumar PP, Lim SH and Tan HTW (2005) Random amplified polymorphic DNA analysis of the moth orchids, Phalaenopsis (Epidendroideae: Orchidaceae). Euphytica 141(1): 11-22.

Griesbach RJ (2002) Development of Phalaenopsis orchids for the mass-market. Trends in new crops and new uses. ASHS Press, Alexandria, VA 458-465.

Gutierrez RMP (2010) Orchids: A review of uses in traditional medicine, its phytochemistry and pharmacology. J. Medicin Plants Res. 4(8): 592-638.

Han YY, Ming F, Wang W, Wang JW, Ye MM and Shen DL (2006) Molecular evolution and functional specialization of chalcone synthase super family from Phalaenopsis orchid. Genetica 128(1-3): 429-438.

Hong PI, Chen JT and Chang WC (2008) Plant regeneration via protocorm-like body formation and shoot multiplication from seed-derived callus of a maudiae type slipper orchid. Acta Physiol. Plant 30(5): 755-759.

Hossain MM, Kant R, Van PT, Winarto B, Zeng and Teixeira Da Silva JA (2013) The application of biotechnology to orchids. Crit. Rev. Plant Sci. 32: 69-139.

Hsiao YY, Tsai WC, Kuoh CS, Huang TH, Wang HC, Wu TS, Leu YL, Chen WH and Chen HH (2006) Comparison of transcripts in Phalaenopsis bellina and Phalaenopsis equestris (Orchidaceae) flowers to deduce monoterpene biosynthesis pathway. BMC Plant Bio. 6(1): 14. 
Hsiao YY, Pan ZJ, Hsu CC, Yang YP, Hsu YC, Chuang YC, Shih HH, Chen WH, Tsai WC and Chen HH (2011) Research on orchid biology and biotechnology. Plant Cell Physiol. 52: 14671486.

Hsu HF, Hsu WH, Lee YI, Mao WT, Yang JY, Li JY and Yang CH (2015) Model for perianth formation in orchids. Nature Plants 1(5): 15046.

Huang JZ, Lin CP, Cheng TC, Chang BCH, Cheng SY, Chen YW, Lee CY, Chin SW and Chen FC (2015). A de novo floral transcriptome reveals clues into Phalaenopsis orchid flower development. PloS one 10(5): e0123474.

Huang JZ, Lin CP, Cheng TC, Huang YW, Tsai YJ and Cheng SY (2016) The genome and transcriptome of Phalaenopsis yield insights into floral organ development and flowering regulation. Peer J. 4: e2017.

Jones AMP and Saxena PK (2013) Inhibition of phenylpropanoid biosynthesis in Artemisia annua L.: A novel approach to reduce oxidative browning in plant tissue culture. PloS one 8(10): e76802.

Kalaiarasan A, Kumar P and John SA (2011) GCMS determination of bioactive components of Bulb ophyllumkaitense Reichib Leaves Eastern Ghats in India. New York Sci. J. 4: 46-49.

Kao YY, Chang SB Lin TY, Hsieh CH, Chen YH, Chen WH and Chen CC (2001) Differential accumulation of heterochromatin as a cause for karyotype variation in Phalaenopsis orchids. Ann. Bot. 87(3): 387-395.

Khoddamzadeh AA, Sinniah UR, Kadir MA, Kadzimin SB, Maziah M and Sreeramanan S (2010) Detection of somaclonal variation by random amplified polymorphic DNA analysis during micropropagation of Phalaenopsis bellina (Rchb.f.) Christenson. Afr. J. Bio. 4(90): 6632-6639.

Khoddamzadeh AA, Sinniah UR, Kadir MA, Kadzimin SB and Maziah M (2011) In vitro induction and proliferation of protocorm-like bodies (PLBs) from Leaf Segments of Phalaenopsis bellina (Rchb.f.) Christenson. Plant Growth Regul. 65(2): 381-387.

Ko YZ, Shih HC, Tsai CC, Ho HH, Liao PC and Chiang YC (2017) Screening transferable microsatellite markers across genus Phalaenopsis (Orchidaceae). Bot Stud 58(1): 48.

Koh, KW, Lee SH, Chen HK, Chang CY and Chan, MT (2018). Phalaenopsis flowering locus VE regulates floral organ maturation. Plant Cell Rep. 37(3): 467-482.

Kosir P, Škof S and Luthar Z (2004) Direct shoot regeneration from nodes of Phalaenopsis orchids. Acta Agric. Slov. 83(2): 233-242.

Kuo HL, Chen JT and Chang WC (2005) Efficient plant regeneration through direct somatic embryogenesis from leaf explants of Phalaenopsis 'Little Steve'. In Vitro Cell Dev BioPlant 41(4): 453.

Kuo PC, Chen GF, Yang ML and Wu TS (2010) High-performance liquid chromatography profiling of from Phalaenopsis hybrids and their contribution to antioxidant and antityrosinase activities. In: International Orchid Symposium 878: 89-95.

Kuo YT, Hsu HL, YehCH and Chang SB (2016) Application of a modified drop method for highresolution pachytene chromosome spreads in two Phalaenopsis species. Molcytogenet 9(1): 44.

Kuo YT, Chao YT, Chen WC, Shih MC and Chang SB (2018) Segmental and tandem chromosome duplications led to divergent evolution of the chalcone synthase gene family in Phalaenopsis orchids. Ann. Bot. 123(1): 69-77. 
Lai T, Deng Y, Zhang P, Chen Z, Hu F, Zhang Q, Hu Y and Shi N (2013) Proteomics-based analysis of Phalaenopsis amabilis in response toward Cymbidium mosaic virus and/or Odonto glossum Ringspot virus infection. Amer. J. Plant Sci 4: 1853-1862.

Leitch IJ, Kahandawala I, Suda J, Hanson L, Ingrouille MJ, Chase MW and Fay MF (2009). Genome size diversity in orchids: consequences and evolution. Ann. Bot. 104(3): 469-481.

Lesar H, Kastelec D and Luthar Z (2012) Asymbiotic seed germination of Phalenopsis Blume orchids after hand pollination. Acta Agric. Slov. 99(1): 5.

Liao LJ, Pan IC, Chan YL, Hsu YH, Chen WH and Chan MT (2004) Transgene silencing in Phalaenopsis expressing the coat protein of Cymbidium mosaic virus is a manifestation of RNA-mediated resistance. Molecul. Breeding 13(3): 229-242.

Ling LF and Subramaniam S (2007) Biochemical analyses of Phalaenopsis violacea orchids. Asian J. Biochem. 2(4): 237-246.

Lin S, Lee HC, Chen WH, Chen CC, Kao YY, Fu YM, Chen YH and Lin TY (2001) Nuclear DNA contents of Phalaenopsis sp. and Doritis pulcherrima. J. Amer. Soc. Hortic. Sci. 126(2): 195-199.

Liu WL, Shih HC, Weng IS, Ko YZ, Tsai CC, Chou CH and Chiang YC (2016a) Characterization of genomic inheritance of intergeneric hybrids between Ascocenda and Phalaenopsis cultivars by GISH, PCR-RFLP and RFLP. PloS one 11(4): e0153512.

Liu TH, Wu JD, Chang YCA and Lee CK (2016b) LC-MS-based metabolomics study on the effects of light qualities on Phalaenopsis. Planta Med. 81(S 01): P60.

Liu YC, Tseng KM, Chen CC, Tsai YT, Liu CH, Chen WH and Wang HL (2013) Warm-night temperature delays spike emergence and alters carbon pool metabolism in the stem and leaves of Phalaenopsis aphroide. Sci. Hort. 161: 198-203.

Manako Y, Wake H, Tanaka T, Shimomura K and Ishimaru K (2001) Phenanthropyran derivatives from Phalaenopsis equestris. Phytochem. 58(4): 603-605.

Marasini R and Joshi S (2013) Antibacterial and antifungal activity of medicinal orchids growing in Nepal. J. Nepal Chem. Soc. 29: 104-109.

Martin KP and Madassery J (2006) Rapid in vitro propagation of Dendrobium hybrids through direct shoot formation from foliar explants, and protocorm-like bodies. Sci Hort. 108(1): 95-99.

Mayer JLS, Stancato GC and Appezzato-Da-Glória B (2010) Direct regeneration of protocorm-like bodies (PLBs) from leaf apices of Oncidium flexuosum Sims (Orchidaceae). Plant Cell Tissue Organ Cult. 103(3): 411-416.

Minh TN, Khang DT, Tuyen PT, Anh LH, Quan NV, Ha PTT, Quan NT, Toan NP, ElzaawelyAA and Xuan TD (2016) Phenolic compounds and antioxidant activity of Phalaenopsis orchid hybrids. Antioxidants 5(3): 31.

Minh TN, Tuyen PT, Khang DT, Quan NV, Ha PTT, Quan NT, Andriana Y, Fan X, Van TM, KhanhTD and Xuan TD (2017) Potential use of plant waste from the moth orchid (Phalaenopsis Sogo Yukidian "V3") as an antioxidant source. Foods 6(10): 85.

Ng CKY and Hew CS (2000) Orchid pseudobulbs-false 'bulbs with a genuine importance in orchid growth and survival! Sci. Hort. 83(3): 165-172.

Niknejad A, Kadir MA, Kadzimin SB, Abdullah NAP and Sorkheh K (2009) Molecular characterization and phylogenetic relationships among and within species of Phalaenopsis (Epidendroideae: Orchidaceae) based on RAPD analysis. Afr. J. Bio. 8(20). 
Niknejad A, Kadir MA and Kadzimin SB (2011) In vitro plant regeneration from protocorms-like bodies (PLBs) and callus of Phalaenopsis gigantea (Epidendroideae: Orchidaceae). Afr. J. Bio. 10(56): 11808-11816.

Niu SC, Xu Q, Zhang GQ, Zhang YQ, Tsai, WC, Hsu JL, Liang CK, Luo YB and Liu ZJ (2016) De novo transcriptome assembly databases for the butterfly orchid Phalaenopsis equestris. Sci. data 3: 160083.

Nurhayati N, Gondé D and Ober D (2009) Evolution of pyrrolizidine alkaloids in Phalaenopsis orchids and other monocotyledons: Identification of deoxyhypusine synthase, homospermidine synthase and related pseudogenes. Phytochemist 70(4): 508-516.

Ober D and Kaltenegger E (2009) Pyrrolizidine alkaloid biosynthesis, evolution of a pathway in plant secondary metabolism. Phytochemist 70(15): 1687-1695.

Ouzounis T, Fretté X, Rosenqvist E and Ottosen CO (2014) Effects of LEDs on chlorophyll fluorescence and secondary metabolites in Phalaenopsis. In: International Orchid Symposium 1078: 87-92.

Paek KY, Hahn EJ and Park SY (2011) Micropropagation of Phalaenopsis orchids via protocorms and protocorm-like bodies. Plant Embryo Culture: Methods and Protocols. 293-306.

Pant S and Rinchen T (2012) Dactylorhiza hatagirea: A high value medicinal orchid. J. Med. Plants Res. 6(19): 3522-3524.

Pressi G, Dal Toso R and Sgaravatti E (2014) U.S. Patent No. 8,709,810. Washington, DC: U.S. Patent and Trademark Office.

QasemJR and Foy CL (2001) Weed allelopathy, its ecological impacts and future prospects: A review. J. Crop Prod. 4(2): 43-119.

Qin XY, Liu Y, Mao SJ, Li TB, Wu HK, Chu CC and Wang YP (2011) Genetic transformation of lipid transfer protein encoding gene in Phalaenopsis amabilis to enhance cold resistance. Euphytica 177(1): 33-43.

Raynalta E, Elina J, Sudarsono S and Sukma D (2018) Clonal fidelity of micropropagated phalaenopsis plantlets based on assessment using eighteen Ph-Pto SNAP marker loci. AGRIVITA, J. Agri. Sci. 40(3).

Sheelavanthmath SS, Murthy HN, Hema BP, Hahn EJ and Paek KY (2005) High frequency of protocorm like bodies (PLBs) induction and plant regeneration from protocorm and leaf sections of Aeridescrispum. Sci. Hort. 106(3): 395-401.

Shefferson RP, Weiss M, Kull TII and Taylor DL (2005) High specificity generally characterizes mycorrhizal association in rare lady's slipper orchids, genus Cypripedium. Molecul Ecol. 14(2): 613-626.

Sinha P, Alam MF and Hakim ML (2010) Micropropagation of Phalaenopsis Blume. Protocols for In Vitro Propagation of Ornamental Plants. 77-85.

Smaczniak C, Immink RG, Muiño JM, Blanvillain R, Busscher M, Busscher-Lange J, Dinh QP, Liu S, Westphal AH, Boeren S and Parcy F (2012) Characterization of MADS-domain transcription factor complexes in Arabidopsis flower development. Proceedings of the National Academy of Sciences 109(5): 1560-1565.

Su CL, Chao YT, Alex Chang YC, Chen WC, Chen CY, Lee AY, Hwa KT and Shih MC (2011) De novo assembly of expressed transcripts and global analysis of the Phalaenopsis aphrodite transcriptome. Plant Cell Physiol. 52(9): 1501-1514. 
Su Cl, Chao YT, Yen SH, Chen CY, Chen WC, Alex Chang YC and Shin MC (2013) Orchidstra: an integrated orchid functional genomics database. Plant Cell Physiol. 54 (2): e11.

Teixeira da Silva JA, Kerbauy GB, Zeng S, Chen Z and Duan J (2014) In vitro flowering of orchids. Crit. Rev. Biotech. 34(1): 56-76.

Teoh ES 2016. Secondary Metabolites of Plants. In: Medicinal Orchids of Asia (pp. 59-73). Springer International Publishing.

Tsai WC, Hsiao YY, Lee SH, Tung CW, Wang DP, Wang HC, Chen WH and Chen HH (2006) Expression analysis of the ESTs derived from the flower buds of Phalaenopsis equestris. Plant Sci. 170(3): 426-432.

Tsai CC (2011) Molecular phylogeny and biogeography of Phalaenopsis species. Orchid Biotechnology. II. World Scientific, Singapore. 1-24.

Tsai WC, Fu CH, Hsiao YY, Huang YM, Chen LJ, Wang M, Liu ZJ and Chen HH (2013) Orchid Base 2.0: Comprehensive collection of Orchidaceae floral transcriptomes. Plant Cell Physiol. 54 (2): e7.

Tsai CC, Shih HC, Wang HV, Lin YS, Chang CH, Chiang YC and Chou CH (2015) RNA-seq SSRs of moth orchid and screening for molecular markers across genus Phalaenopsis (Orchidaceae). PloS one 10(11): e0141761.

Tsai CC, Wu YJ, Sheue CR, Liao P, Chen YH, Li SJ, Liu JW, Chang HT, Liu WL, KoYZ and Chiang YC (2017) Molecular basis underlying leaf variegation of a moth orchid mutant (Phalaenopsis aphrodite subsp. formosana). Front Plant Sci. 8: 1333.

Van Bel M, Diels T, Vancaester E, Kreft L, Botzki A, Van de Peer Y, Coppens F and Vandepoele K (2018) PLAZA 4.0: An integrative resource for functional, evolutionary and comparative plant genomics. Nucleic Acids Res 46(D): D1190-1196.

Vasil IK (2008) A history of plant biotechnology: From the cell theory of Schleiden and Schwann to biotech crops. Plant Cell Reports 27(9): 1423.

Vendrame W and Khoddamzadeh AA (2016) Orchid Biotechnology. Jules Janick (Ed.), Horticultural Reviews 44: 173-228.

Xu C, Zeng B, Huang J, Huang W and Liu Y (2015) Genome-wide transcriptome and expression profile analysis of Phalaenopsis during explant browning. PloS one 10(4): e0123356.

Yeh YC, Tsay YS, Shih CT, and Huang P (2014) Selection and breeding of scented Phalaenopsis varieties. Agric. Policy Agric. Situation 26797.

Yeung EC (2017) A perspective on orchid seed and protocorm development. Botanical Studies 58(1): 33.

Yonzone R, Kamran A and Bhujel RB (2012) Orchids in Ethnobotany. In: Proceeding volume, International Seminar on Multidisciplinary Approaches in Angiosperm Systematic 661-669. 